\title{
An Analysis of Taiwanese Aboriginal Students’ Educational Aspirations
}

\author{
Hou, Hsiao-I (Corresponding author) \\ Visiting Professor, School of Hospitality, Recreation and Tourism, Humber College \\ 205 Humber College Blvd., Toronto M9W 5L7, Ontario, Canada \\ Tel: 1-416-675-6622 ext $5518 \quad$ E-mail: houx0020@gmail.com \\ Huang, Chia-Kai \\ Research Assistant, Taiwan Higher Education Society \\ NO.151 Yingzhuan Rd., Danshui Dist., New Taipei City 251, Taiwan (R.O.C.) \\ c/o Graduate Institute of Educational Policy and Leadership, Tamkang University, Taiwan \\ Tel: 886-927-552-289Ｅ-mail: hiki329@gmail.com
}

Received: February 28, 2012 Accepted: March 5, 2012 Online Published: May 2, 2012

doi:10.5539/hes.v2n2p79

URL: http://dx.doi.org/10.5539/hes.v2n2p79

\begin{abstract}
By analysing the national data from the Junior Survey of the Taiwan Higher Education Dataset, this study identified significant variables influencing the educational aspirations of aboriginal students at technical and vocational institutions. The study shows that several variables are predictive of the educational aspirations of aboriginal students. Institutional types, more weekly hours of lessons, more time spent on assignment preparation and revision, a higher maternal educational level, a higher GPA, a keen participation in autonomous, academic, or extramural club activities, and a higher self-rating of interpersonal skills are all associated with higher educational aspirations. In contrast, being a female student and a keen participant in musical and sports club activities are associated with lower educational aspirations. Recommendations to improve Taiwanese aboriginal students' educational aspirations are discussed.
\end{abstract}

Keywords: Aboriginal student, Educational aspiration

\section{Introduction}

Modern historians believe that Taiwanese Aboriginals arrived from Southeast Asia fifteen thousand years ago. Their native languages are identified as originating from Austronesian languages (Rubinstein, 2007). They occupied both the coastal lowlands and the mountainous uplands until the arrival of the Dutch in the seventeenth century. Historical records indicate that an estimated 70000 Aborigines lived in small villages on the west coast of the island during the early years of Dutch occupation, but, new migrants from mainland China quickly came and outnumbered the native settlers (Stainton, 2007). The Han Chinese group eventually became the majority in Taiwanese society, whereas the aborigines became the minority. Since aboriginal culture and physical attributes quite unique, the government and the people of Taiwan have worked since the 1990s to keep their culture and language alive. With a population near 484000 (1.9\%) in Taiwan, Aboriginal Taiwanese continue to play an active role in building the future of Taiwanese culture.

The reforms of educational policies in recent years have led to a proliferation of tertiary education in Taiwan. By the end of 2011 the number of tertiary institution increased to 163 (Table 1), and especially, the number for four-year universities and vocational institutions has more than doubled since 1996. Student numbers have also increased steadily as compared to past years. By the end of 2011 students of tertiary education in Taiwan exceeded 1.29 million (Table 2). Tertiary education in Taiwan is booming. This expansion has seen tertiary education become more accessible to the general public, which is consistent with Trow (1974) who observed that the rapid expansion of tertiary education in different countries would mean that tertiary education has turned from elite education to mass education.

In Taiwan, aboriginal people account for less than two percent of the country's population (Ministry of Education, 1997; Executive Yuan, 2002). This population proportion reflects itself in tertiary education. Although the 
proportion of aboriginal students receiving tertiary education is increasing, the vast majority are non-aboriginal students and less than two percent are aboriginal students (see in Table 2).

According to the data from the Ministry of Education (MOE) in Taiwan, in the 2010 academic year 82.95 percent of aboriginal students were enrolled in high school, whereas figures for non-aborigines students were 70.11 percent. For higher education levels, about 17 percents of aboriginal students enrolled in undergraduate and graduate programs. Nearly 30 percent of non-aborigines attended tertiary level programs. The data show that more non-aboriginal students continue their higher studies after they finish their high school programs. In the same academic year, the dropout rate and deferral rate for aboriginal students is higher than the non-aboriginal ones (Department of Statistics, 2011c). This data could imply that aboriginal students probably have more difficulties attaining or continuing their higher studies than their non-aboriginal counterparts. These results are consistent with the view that although there is scope for substantial development regarding the quality and quantity of aboriginal education, problems such as learning difficulties, lower educational achievement, and higher dropout rates are prevalent (Tan, 2000). However, issues related to aboriginal students' educational problems in Taiwan are not well discussed or fully investigated in the literature. There is a considerable room for improving educational quality and quantity for this group of students at the tertiary level.

Supportive and beneficial programs have been implemented in the form of social welfare, scholarships, special enrolment policies, tuition waivers, and income subsidy to Taiwanese Aboriginal families and students. Some aboriginal elites have shown outstanding performance both in educational and occupational fields. However, the majority of aboriginal people are still trapped in an adverse environment that is not conducive to effective education (MOE, 1997). Their social minority status disadvantages them in the education system. The social and educational disadvantages will impede their future social mobility and development. Therefore, an understanding of the aspirations of aboriginal students will help elucidate the difficulties and challenges they face at the tertiary level.

This study relies on the College Student Developmental Theory (Pascarella \&Terenzini, 2005) and the Career Motivation Model (Farmer, 1985) to explore the educational aspirations of aboriginal students enrolled in vocational institutions in Taiwan. Because of Taiwan's unique education system and enrolment channels, top students are usually enrolled at a public four-year comprehensive university. Vocational and private institutes are ranked lower and students on a vocational track are trained for their future career development, not for advanced educational training. Since tertiary education is an important stage for an individual's future social mobility, some aboriginal students in the vocational track still hope that they can continue their future study, or at least finish their tertiary education. The aim is to identify the significant indicators of education aspirations of aboriginal students, and it is believed that these indicators can predict their motivation. It is hoped that this study's results can provide significant information to school administrators or counsellors to assist aboriginal students' future achievements in educational success.

\section{Literature Review}

This section will discuss current research outcomes related to some impacts on students' development and some other factors that influence their success in schools, which will be the foundation for the present study. Relevant literature in Taiwanese and international contexts are reviewed.

\subsection{Student Development Issues}

Based on the context in Taiwan, among the factors that influence the educational attainment of minority students, Tan (2000) identified several factors that have negative influences on the schooling of aboriginal students. These factors included cultural differences, communication problems, group identity, interpersonal relationships, and socio-economic differences. These unfavourable factors impede the learning process of aboriginal students and could inadvertently place a limit on their aspirations. As a result, aboriginal people are unable to climb the social ladder through educational attainment. This vicious cycle is detrimental to the improvement of the socio-economic status of aboriginal people and the future of aboriginal students.

An understanding of students' expectations toward education and their career aspirations is important, especially for their developmental stages at the tertiary level. Liu (2008) has studied the relationships between expectations of education, university life, learning outcomes, and university satisfaction among Taiwanese students of tertiary education. The results show that students' satisfaction levels were related to their university life and learning outcomes. A large discrepancy between a student's expectations and reality are a challenge for both the student and the university. Therefore, universities should foster an accurate sense of expectation in students toward the university, which is also an important factor to consider in decision-making.

In order to identify the factors associated with dropout/continuation of study among vocational college students in 
Taiwan, Lin (2008) has studied 807 freshmen from 13 four-year vocational institutions in north Taiwan. The results showed that students' self-efficacy has a positive influence on their academic and social integration. Self-efficacy is also the most important psychological factor in determining students' adjustment to university life and their decision regarding whether to continue with their study. These findings indicate that academic advisors or counsellors should be aware of the influences of compromised self-efficacy among university freshmen and provide adequate guidance so that these students can finish their study successfully.

Chen and Ma (2007) have studied the enrolment status, economical burden, and intention for further education among Taiwanese aboriginal students at the tertiary level. They found that a larger proportion of students with a lower economic status were enrolled in private vocational colleges. In addition, aboriginal students tended to rely on scholarships and student loans to finish university education and to pursuit their further study. It could be seen that in general aboriginal students are financially disadvantaged in their pursuit of tertiary education. This study shows similar results as Smedley, Myers and Harrell's (1993). Aboriginal freshmen tend to have lower academic achievement because of their minority background and lower social-economic status, which might explain the higher deferral and dropout rates among aboriginal students in tertiary education.

In a study of the relationships among developmental status, self-efficacy, and difficulties faced on campus for university students, Gao and $\mathrm{Li} \mathrm{(2001)}$ and $\mathrm{Li}$ (2001) found that reaction to difficulties associated with group identity were more intense among aboriginal students than non-aboriginal students. In contrast, aboriginal students have more challenges in future life paths and academic learning than do non-aboriginal students. These findings showed that although aboriginal university students are better assimilated into the mainstream culture than their less educated counterparts, group identity is still influential in their adjustment to university life and development. This echoes the view of Tan (2000) that cultural identity greatly influences personal values on education and learning motivations of young minority groups.

Recent international research has shown that gender (Dawkins, 1981; Kelly \& Wingrove, 1985), parental income (Picou, 1973), parental educational level (Farmer \& Chung, 1995), parental occupation (Allen, 1978), academic performance (Dawkins, 1989), self-estimates (Burke \& Hoelter, 1988), perceived likelihood of completing university degree (Dawkins, 1981) and financial assistance (Farmer \& Chung, 1995) are all important variables that influence academic and vocational attainments and aspirations of university students. According to the College Student Developmental Theory (Pascarella \& Terenzini, 2005), factors such as behavioural models of weekly activity, interpersonal attitudes, personal values, and attitudes toward university attendance are also influential on students' aspirations of their career and future achievement. This study set out to examine these factors, as they were included in the aforementioned research.

\subsection{Farmer's Model}

The variables of this study were constructed based on Farmer's (1985) Career Motivation Model. Educational aspiration is one of the important variables in the model, and is also an important predictor for future achievement of an individual. The original model proposed by Farmer was based on the social learning theory, which comprises three core factors, namely, background, individual, and environment. Background factors include demographic details such as gender, social status, ethnicity, and age. Individual factors include psychological and self-appraisal factors such as academic success, sexual preference, and developmental paths of future accomplishment. Environmental factors comprise societal factors such as parental support and teacher's influence. Recent amendments of the Farmer's model have further incorporated other behavioural factors including weekly learning outcomes and performance in student clubs. These four core factors are mutually influential.

Farmer's theory has been widely applied in the research fields of college students' career and educational motivations and decision-making (Chung, 2002; Mau \& Bikos, 2000; Gusheu \& Whitson, 2006; Flores \& O’Brien, 2002). Those studies have shown different results regarding the impacts of background factors and individual factors such as gender, ethnicity, and self-efficacy on career or educational aspirations. Positive environmental factors including sufficient parental and teachers' support were shown to increase career or educational aspirations. Most of these studies' subjects are African Americans, Hispanic groups, and women in minority groups.

In summary, factors that impede the learning of aboriginal students are multifaceted. These have contributed to an undesirable learning environment for aboriginal students. By identifying the educational aspirations of aboriginal students, this research will help remedy the learning quandary of aboriginal students. Subsequently aboriginal students will have a better chance of completing their study and enjoy greater academic success. Their career and socio-economic status will also be enhanced. 


\section{Methodology}

The data in this study are from the nationwide Junior Survey of the Taiwan Higher Education Dataset, constructed by the Centre for Educational Research and Evaluation in National Taiwan Normal University (Taiwan Higher Education Dataset Project, 2008a). The purpose of establishing the Taiwan Higher Education Dataset is to provide a series of analysis reports that focus on postsecondary education policy issues, and to develop an information system that organizes postsecondary data sets and analyses. There are four components in the dataset: a faculty survey, a freshmen survey, a junior survey, and a graduate survey. The junior survey used a nationally representative sample of students who were in their third year of undergraduate studies in 2005. The survey instrument was developed based on the results from literature reviews and focus group interviews conducted by a committee under the supervision of National Tsinghua University. The instrument focused primarily on the activities of respondents' third year undergraduate life. There were seven sections of the survey, which included: experience in college/university, financial supports, enrolment information, daily life behavioural patterns, future planning, perceptions toward self and the institution, and demographic information. Questions related to opinions, attitudes and behavioural patters were designed in four-point scales. Questions related to self-evaluation in abilities and skills were designed in five-point scales.

The survey period was between October to February of the 2006 academic year. Surveys were distributed either as hard copies or through the Internet. By stratified sampling process, 49609 surveys were distributed and 26307 were returned, amounting to a 53 percent response rate. The missing rate was lower than four percent, thus the current sample is representative of the studied population (Taiwan Higher Education Dataset Project, 2008b). The target population of this study was third-year aboriginal students enrolled in four-year vocational institutions in the 2005 academic year in Taiwan and the total subjects are 857 aboriginal students.

The reasons for adopting the 2005 Junior Survey data are threefold. First, this is the most updated nationwide survey data. Since the student body and number in higher education did not change dramatically in the past years in Taiwan, the data's representation is high and valid. Second, third-year students have more extended experience with the different aspects of university life, both academically and non-academically, and therefore their opinions are more suitable and reliable for the research purposes than those of first-year students. In addition, with their experience at schools, their opinions on the education policy can provide an important reference to policy makers as to whether policy revisions are needed. Third, third-year students will soon graduate, and they are at a point of deciding whether to enter the workforce or to pursue further education. Institutions have to rely on relevant data to tailor their assistance to students. By analysing the data from third-year students, this study aimed to help institutions provide more effective assistance to students so that by the time they reach their fourth-year they would be well prepared to achieve their aspirations, especially for the aboriginal group.

Although the survey was not designed according to the theory proposed by Farmer, several items such as student aspirations, background information, behavioural model, individual, and environmental information are surveyed. Those variables are highly associated with critical issues in College Student Developmental Theory and students' educational aspiration described in the literature review. These predictive variables were categorised into four classes of factors according to Farmer's model, namely, background factors, behavioural factors, personal factors, and environmental factors. Some variables were constructed according to the respondents' answers using factor analysis. This study hypothesised that the educational aspirations of aboriginal students would be influenced by background variables, behavioural variables, individual variables, and environmental variables. The theoretical framework proposed by Farmer was adopted in this study. The framework of the current research was constructed based on the research objective and an analysis of relevant national and international literature (Figure 1).

Table 4 illustrates and explains the selected survey questions as independent variables and their choice items. The dependent variable (educational aspiration) was measured based on students' responses to two questions; 'Any plans to pursuit a higher degree overseas after you graduate?' and 'Any plans to prepare for applying graduate schools in Taiwan after you graduate?' For each question, four choice items were available: 'Never considered', 'Planning', 'In progress', and 'Completed'. The combined score for these two questions was used as the dependent variable.

Based on the types and characteristics of the variables used in this study, quantitative descriptive statistical analysis, chi-square analysis, analysis of variance, factor analysis, and multiple regression analysis were conducted. For a more accurate analysis, data used in the inferential statistical analysis were adjusted according to their weight index. These procedures can reduce measuring errors and hence allow for higher validity and reliability.

\section{Results}

Descriptive analysis shows that 69 percent of aboriginal students were enrolled in private vocational institutions (Table 5); only about thirty percent of the students are in public vocational institutions. Among those students in the 
private sector, 38.4 percent attended private four-year vocational universities, whereas 26.6 percent attended private four-year technical college. Among aboriginal students enrolled in vocational institutions, females outnumbered males ( $54 \%$ to $46 \%$ respectively). In addition, 90.9 percent of Taiwanese Aboriginals' mothers' educational level is below the tertiary education. More specifically, 38.3 percent had a maternal educational level at primary school, 30.8 percent at junior high school, and 21.8 percent at high school or vocational school. Only 9.1 percent had a maternal educational level at the tertiary level.

In regard to paternal educational level, 85.4 percent did not attain the tertiary level. Among them, 28.4 percent had an educational level at primary school, 23.2 percent at junior high school, and 33.8 percent at high school or vocational school. In regard to annual household income, 91.7 percent of aboriginal students had an income lower than New Taiwanese Dollar (NT\$) 1140000 (about US\$ 38 000), whereas 57 percent were below NT\$500 000 (about US\$ 16 666).

Regarding their academic performance, none had achieved an average course mark above 90 percent for the previous semester; 13.1 percent achieved a mark between 80 and 89 percent; 44.6 percent had a mark between 70 and 79 percent; 33.3 percent were in the range of 60 to 69; a further 9 percent achieved a failure mark (lower than 60 percent).

A chi-square analysis of the categorical data is shown in Table 6. There were significant differences in parental educational level and maternal education level by institutional type. For over half of the aboriginal students enrolled in public vocational universities and private vocational colleges, the paternal educational level was below junior high school. For over 70 percent of aboriginal students enrolled in both public and private vocational colleges, the mother's educational level was below junior high school. For over 45 percent of aboriginal students enrolled in private vocational colleges, the mother's educational level was below primary school. There was no significant difference for their household income across institutional type.

There were significant differences in students' participation in club activities (e.g., autonomous club, sports club, community service club, artistic club, general club, literary club, musical club, and extramural club) by institution types (Table 7). Significant differences were also found in weekly Internet usage among students enrolled in different institutions. The number of aboriginal students enrolled in public institutions who would use the Internet for more than 31 hours per week significantly exceeded that of students enrolled in private institutions. There were no significant differences in students' employment status across different institutional types.

A chi-square analysis of individual variables is shown in Table 8 . There were significant differences in self-image among third-year aboriginal students enrolled in different types of institutions. A more positive self-image was reported by students enrolled in private vocational colleges, for example rating themselves as a worthy person who has many virtues. In comparison, aboriginal students enrolled in private vocational universities had less self-confidence. Over half of the aboriginal students enrolled in private vocational colleges thought they did not have attributes that they were proud of. Significant differences were also found in self-estimates across different institutional types, except for computing and information analytical skills. Opinions on the functions of university education, such as the function of expanding knowledge and intellectual horizons, strengthening competitiveness in the work place, providing networking opportunities, and increasing knowledge about the world, society, and environment, differed significantly among aboriginal students enrolled in different types of institutions. In addition, students' opinions on different life goals, such as undertaking meaningful work, having an extraordinary contribution in certain areas, becoming an entrepreneur, having a happy family, and mastering a foreign language, differed significantly across different types of institutions. In conclusion, students enrolled in public vocational institutions have more positive attitudes toward themselves in self-image, English ability, and their future life-goals than those in private institutions.

Analyses of equality of group means for the quantitative data are summarized in Table 9. Significant differences were found in credits registered per semester and time spent on physical exercise, leisure activities, and study among aboriginal students enrolled in different types of institutions. Students in the public sector took more credits per semester and spent more time on assignments and outdoor activities than students in the private system. Compared to other institutions, aboriginal students enrolled in private universities spent more time on leisure activities.

To provide a thorough understanding of the influence of the different variables on the educational aspirations of third-year aboriginal students enrolled in vocational institutions, a regression model was used to further explore the mechanism through which different variables influence the educational aspirations of aboriginal students. Our predictive model was able to account for 29.3 percent of the variance observed in the educational aspirations of aboriginal students $\left(\mathrm{R}^{2}=0.293, \mathrm{p}<.001\right.$; Table 10$)$.

Table 10 shows that several variables were significant predictors of the educational aspirations of aboriginal students 
enrolled in vocational institutions. Enrolment in vocational universities, a higher self-rating on interpersonal skills, taking more credits per semester, more time spent on assignment preparation and revision, a higher mother's educational level, a higher GPA, a keen participation in autonomous, academic, and extramural club activities were all predictive of a higher educational aspiration of aboriginal students enrolled in vocational institution. In contrast, being a female student and a keen participant in musical and sports club activities were associated with a lower educational aspirations among aboriginal students.

\section{Conclusions and Recommendations}

Research conducted in Taiwan showed that aboriginal students have a lower academic achievement and a lower motivation than non-aboriginal students (Tan, 2000; Li, 2001; Gao \& Li; 2001; Chen \& Ma, 2007). The present research results further suggest that the type of institutions attended by aboriginal students also has an effect on their educational aspirations. Therefore, assistance at varying levels can be provided by the educational institutions to enhance their learning motivation. This study recommends that for vocational colleges, assistance provided to aboriginal students regarding further education should be strengthened. For instance, it is important to hire professional counsellors to consult students' special needs both in life and academia. The professionals can provide them with comprehensive information about graduate school programs or overseas study, and hosting workshops including test preparation skills or graduation school application process can increase their educational aspirations.

The current results show that club participation is a significant factor influencing the educational aspirations of aboriginal students enrolled vocational institutions. It is therefore recommended that aboriginal students should be encouraged to participate in autonomous (e.g., department student associations, student unions), literary (e.g., calligraphy club, comic book club), or extramural club activities. Research conducted overseas has also shown that participation in club activities improved students' interpersonal skills (Astin, 1996; Pascarella \& Terenzini, 1998; 2005). Therefore, types of clubs and time spent on club activities are significant factors to influence aboriginal students' future educational aspirations.

In regard to parental educational level, a lower mother's educational level was associated with lower educational aspirations for aboriginal students. It is therefore suggested that mentoring and tailored guidance regarding future education plans should be provided at an early stage to aboriginal students whose mothers have lower educational levels. Also, education institutions should design a supportive environment to encourage aboriginal students to spend more time on their schoolwork. For example, the school can extend the library hours or design study areas in the library or in student residence buildings to create a positive learning environment for students. Aboriginal students should be encouraged to spend more time on class preparation and revision. These measures should lead to a higher aspiration among aboriginal students.

Finally, female aboriginal students and those who participated keenly in musical or sports club activities had lower educational aspirations. Similar results were obtained for those who had a lower GPA. It is suggested that more school-based assistance should be provided to these students. They should be encouraged to participate in other types of club activity so as to broaden their learning experience. It is also helpful to encourage these students to think about their future and construct their own roadmaps.

This study provides a preliminary analysis of the educational aspirations of aboriginal students enrolled in vocational institutions in Taiwan. Through the use of a national database, a number of factors were identified as related to the educational aspirations of aboriginal students. Some of these factors were neglected by previous research, such as institutional type and student club participation. Future research can examine whether there is any difference in aspirations between aboriginal students enrolled in vocational institutions and those enrolled in other types of institutions. This can contribute to a more thorough understanding of aboriginal students. In addition, the Ministry of Education in Taiwan should continue to conduct nationwide surveys, build comprehensive longitudinal datasets, and release these types of national data to public to encourage educational research. These types of data are important because they can provide reliable and useful information for longitudinal analyses. Such analytic results are important resources for future educational policymaking and education reform implementation.

\section{References}

Allen, W. (1978). Race, family setting, and adolescent achievement orientation. Journal of Negro Education, 47, 230-243. http://dx.doi.org/10.2307/2294598

Astin, A. (1996). The role of service in higher education. About Campus, 1, 14-19.

Burke, P., \& Hoelter, J. (1988). Identity and sex-race differences in educational and occupational aspirations formation. Social Science Research, 17, 29-47. http://dx.doi.org/10.1016/0049-089X(88)90019-1

Chen, P., \& Ma, G. (2007). A study of the enrolment status, economical burden, and intention for further education 
among Aboriginal students at the tertiary level. Integrated Higher Education Database System in Taiwan, 7, 1-22. [Online] Available: http://info.cher.ed.ntnu.edu.tw/epaperi/prevcato/topics/download.php?file=20070328.pdf (September 8, 2009)

Chung, B. (2002). Career decision-making self-efficacy and career commitment: Gender and ethnic differences among college students. Journal of Career Development, 28(4), 277-284. http://dx.doi.org/10.1023/A:1015146122546

Council of Indigenous Peoples, Executive Yuan (2002). 2002 statistical yearbook of Taiwan Aborigines. [Online] Available: http://www.apc.gov.tw/chinese/docDetail/detail_EVALUATE.jsp?docid=PA000000001193 (September 8, 2012)

Dawkins, M. (1981). Mobility aspirations of Black adolescents. Adolescence, 16, 701-710.

Dawkins, M. (1989). The persistence of plans for professional careers among Blacks in early adulthood. Journal of Negro Education, 58, 220-231. http://dx.doi.org/10.2307/2295595

Department of Statistics (2011a). Profile of schools at all levels (80th - 100th academic year). [Online] Available: http://www.edu.tw/files/site_content/b0013/b.xls (February 12, 2012)

Department of Statistics (2011b). Profile of aboriginal students (87th - 100th academic year). [Online] Available: http://www.edu.tw/files/site_content/b0013/ob1.xls (February 12, 2012)

Department of Statistics (2011c). 98th Profile of Aboriginal students (87th - 100th academic year). [Online] Available: http://www.edu.tw/files/site_content/B0013/99native.pdf (February 12, 2012)

Farmer, H. S., \& Chung, Y. B. (1995). Variables related to career commitment, mastery motivation, and level of career aspiration among college students. Journal of Career Development, 21(4), 265-278.

Farmer, H. S. (1985). Model of career and achievement motivation for women and men. Journal of Counselling Psychology, 32, 363-390._http://dx.doi.org/10.1037/0022-0167.32.3.363

Flores, L., \& Obrien, K. (2002). The career development of Mexican American adolescent women: A test of social cognitive career theory. Journal of Counselling Psychology, 49(1), 14-27. http://dx.doi.org/10.1037/0022-0167.49.1.14

Gao, S., \& Li, Y. (2001). An exploratory study of the university life and its obstacles for aboriginal students. Published in 'The 90th annual seminar of published scientific papers on Aboriginal education' hosted by National Hsinchu University of Education, 78-92.

Gushue, G., \& Whitson, M. (2006). The relationship among support, ethnic identity, career decision self-efficacy, and outcome expectations in African American high school students. Journal of Career Development, 33(2), 1120124. http://dx.doi.org/10.1177/0894845306293416

Kelly, P., \& Wingrove, C. (1985). Educational and occupational choices of Black and White, male and female students in a rural Georgia community. Journal of Research and Development in Education, 9, 45-56.

Li, Y. (2001). Study of the relationship between university life, self-efficacy, and difficulties faced on campus by aboriginal students. Master thesis of National Hsinchu University. Electronic Theses and Dissertations System, 090NHCTC576005.

Lin, X. (2008). 'Study of factors associated with dropout/continuation among vocational college students - students enrolled in vocational colleges in Taipei area’ Abstract. Integrated Higher Education Database System in Taiwan, 17, 9-14. [Online] Available: http://info.cher.ed.ntnu.edu.tw/epaperi/prevcato/topics/download.php?file=20080131.pdf (September 8, 2010)

Liu, R. (2008). The relationship between expectations of education, university life, learning outcomes, and university satisfaction among students of tertiary education. Integrated Higher Education Database System in Taiwan, 20, [Online] Available: http://info.cher.ed.ntnu.edu.tw/epaperi/prevcato/topics/download.php?file=20080430.pdf (September 8, 2010)

Mau, W., \& Bikos, L. (2000). Educational and vocational aspirations of minority and female students: A longitudinal study. Journal of Counseling \& Development, 78(2), 186-194. http://dx.doi.org/10.1002/j.1556-6676.2000.tb02577.x Ministry of Education (1997). Report on Aboriginal education in Republic of China. Taipei: Ministry of Education.

Pascarella, E., \& Terenzini, P. (1998). Studying college students in the 21st century: Meeting new challenges. Review of Higher Education, 21, 151-165.

Pascarella, E., \& Terenzini, P. (2005). How college affects students: A third decade of research. San Francisco, CA: 
Jossey-Bass Publishers.

Picou, J. (1973). Black-White variations in a model of the occupational aspiration process. Journal of Negro Education, 42, 117-122. http://dx.doi.org/10.2307/2967007

Rubinstein, M. (2007). Taiwan: A new history. New York, NY: East Gate Book.

Smedley, B. D., Myers, H. F., \& Harrel, S. P. (1993). Minority-Status Stress and the College Adjustment of Ethnic Minority Freshman. Journal of Higher Education, 64(4), 434-451. http://dx.doi.org/10.2307/2960051

Stainton, M. (2007). The politics of Taiwan aboriginal origins. In Murray Rubinstein (eds.), Taiwan: A new history. New York, NY: East Gate Book. 27-44.

Taiwan Higher Education Dataset Project (2008a). Database introduction. [Online] Available: http://www.cher.ed.ntnu.edu.tw/introduction.php (September 14, 2010)

Taiwan Higher Education Dataset Project (2008b). Statistical data files. [Online] Available: http://www.cher.ed.ntnu.edu.tw/analyze.php (September 9, 2010)

Tan, G. (2000). Aboriginal education research. Taipei: Wunan.

Trow, M. (1974). Problems in the Transition from Elite to Mass Higher Education, In Policies for Higher Education: A General Report, Paris: OECD, Conference. On Future Structures of Post-Secondary Education, 26th-29th June, 1973, 51-1

Table 1. Number of tertiary education institutions in Taiwan by academic year

\begin{tabular}{|c|c|c|c|c|c|c|c|c|c|c|c|}
\hline \multirow{2}{*}{$\begin{array}{l}\text { Institution } \\
\text { Yea }\end{array}$} & \multicolumn{3}{|c|}{ University } & \multicolumn{3}{|c|}{$\begin{array}{l}\text { 4- year vocational } \\
\text { institute }\end{array}$} & \multirow{2}{*}{ Total } & \multicolumn{3}{|c|}{ 2-year vocational college } & \multirow{2}{*}{ Total } \\
\hline & $\begin{array}{l}\text { Publi } \\
\text { C }\end{array}$ & $\begin{array}{l}\text { Privat } \\
\mathrm{e}\end{array}$ & Subtotal & Public & Private & \begin{tabular}{|l} 
Subtota \\
l
\end{tabular} & & $\begin{array}{l}\text { Publi } \\
\text { C }\end{array}$ & Private & Subtotal & \\
\hline 1996 & 16 & 8 & 24 & 21 & 22 & 43 & 67 & 14 & 56 & 70 & 137 \\
\hline 2001 & 27 & 30 & 57 & 23 & 55 & 78 & 135 & 3 & 16 & 19 & 154 \\
\hline 2006 & 41 & 53 & 94 & 11 & 42 & 53 & 147 & 3 & 13 & 16 & 163 \\
\hline 2009 & 42 & 63 & 105 & 9 & 35 & 44 & 149 & 3 & 12 & 15 & 164 \\
\hline 2010 & 45 & 67 & 112 & 6 & 30 & 36 & 148 & 3 & 12 & 15 & 163 \\
\hline 2011 & 46 & 70 & 116 & 5 & 27 & 32 & 148 & 3 & 12 & 15 & 163 \\
\hline
\end{tabular}

Source: Department of Statistics (2011a)

Table 2. Number of students enrolled in tertiary education institutions in Taiwan

\begin{tabular}{|c|c|c|c|c|}
\hline & \multirow[b]{2}{*}{ Student Number } & \multicolumn{2}{|c|}{ Aboriginal Student } & \multirow[b]{2}{*}{$\begin{array}{l}\text { Aboriginal Students } \\
(\%)\end{array}$} \\
\hline Year & & Student Number & $\begin{array}{ll}\text { Proportion } & \text { Increase } \\
\text { from } & \text { Previous } \\
\text { Academic } & \text { Year (\%) }\end{array}$ & \\
\hline 2001 & 1092878 & 7637 & - & 0.70 \\
\hline 2002 & 1157718 & 8816 & 15.44 & 0.76 \\
\hline 2003 & 1202091 & 9927 & 12.60 & 0.83 \\
\hline 2004 & 1125466 & 12482 & 15.00 & 1.11 \\
\hline 2005 & 1245229 & 12063 & 7.39 & 0.97 \\
\hline 2006 & 1263977 & 13881 & 15.07 & 1.10 \\
\hline 2007 & 1274322 & 13658 & \begin{tabular}{|l|}
-1.61 \\
\end{tabular} & 1.07 \\
\hline 2008 & 1285896 & 14850 & 8.73 & 1.15 \\
\hline 2009 & 1284473 & 16281 & 9.64 & 1.27 \\
\hline 2010 & 1290176 & \begin{tabular}{|l|}
17684 \\
\end{tabular} & 8.62 & 1.37 \\
\hline 2011 & 1297096 & 19811 & 12.03 & 1.53 \\
\hline
\end{tabular}

Source: Department of Statistics (2011 a, b); 
Table 3. Year 2010 student body and deferral/dropout rates for tertiary institutions in Taiwan

\begin{tabular}{|l|l|l|l|l|}
\hline & & $\begin{array}{l}\text { Non-Aboriginal } \\
\text { student }\end{array}$ & $\begin{array}{l}\text { Aboriginal } \\
\text { student }\end{array}$ & Total \\
\hline \multirow{3}{*}{ Structure of student body (\%) } & Graduate & 4.93 & 0.85 & \\
\cline { 2 - 5 } & Undergraduate & 24.96 & 16.20 & \\
\cline { 2 - 5 } & High-school or below & 70.11 & 82.95 & \\
\hline Dropout rates for tertiary students (\%) & & 2.21 & 3.99 & 2.24 \\
\hline Deferral rates for tertiary students (\%) & & 5.66 & 7.43 & 5.69 \\
\hline
\end{tabular}

Source: Department of Statistics (2011 c)

Table 4. Research questions and variables

\begin{tabular}{|c|c|}
\hline Questions & Response items \\
\hline \multicolumn{2}{|l|}{ Background variables } \\
\hline Gender & 1.Male 2.Female \\
\hline Paternal educational level & $\begin{array}{l}\text { 1. Primary school or below } \\
\text { 2. Junior high school } \\
\text { 3. High school or vocational school } \\
\text { 4. Community college } \\
\text { 5. University } \\
\text { 6. Graduate school or above }\end{array}$ \\
\hline Mother's educational level & $\begin{array}{l}\text { 1. Primary school or below } \\
\text { 2. Junior high school } \\
\text { 3. High school or vocational school } \\
\text { 4. Community college } \\
\text { 5. University } \\
\text { 6. Graduate school or above }\end{array}$ \\
\hline Annual household income & 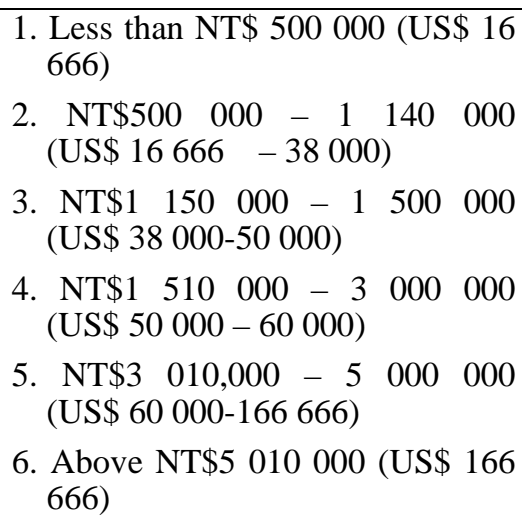 \\
\hline Behavioural variables & \\
\hline GPA & \\
\hline $\begin{array}{l}\text { Participation in social clubs } \\
\text { 1. Autonomous club activities (e.g., department student association, student } \\
\text { union) } \\
\text { 2. Sports club activities (e.g., sport team, kendo team) } \\
\text { 3. Community service club activities (e.g., scouts club) } \\
\text { 4. Artistic club activities (e.g., art club, dance club) } \\
\text { 5. General club activities (e.g., alumni association) }\end{array}$ & $\begin{array}{l}\text { 1. Never } \\
\text { 2. Seldom } \\
\text { 3. Sometimes } \\
\text { 4. Often }\end{array}$ \\
\hline
\end{tabular}




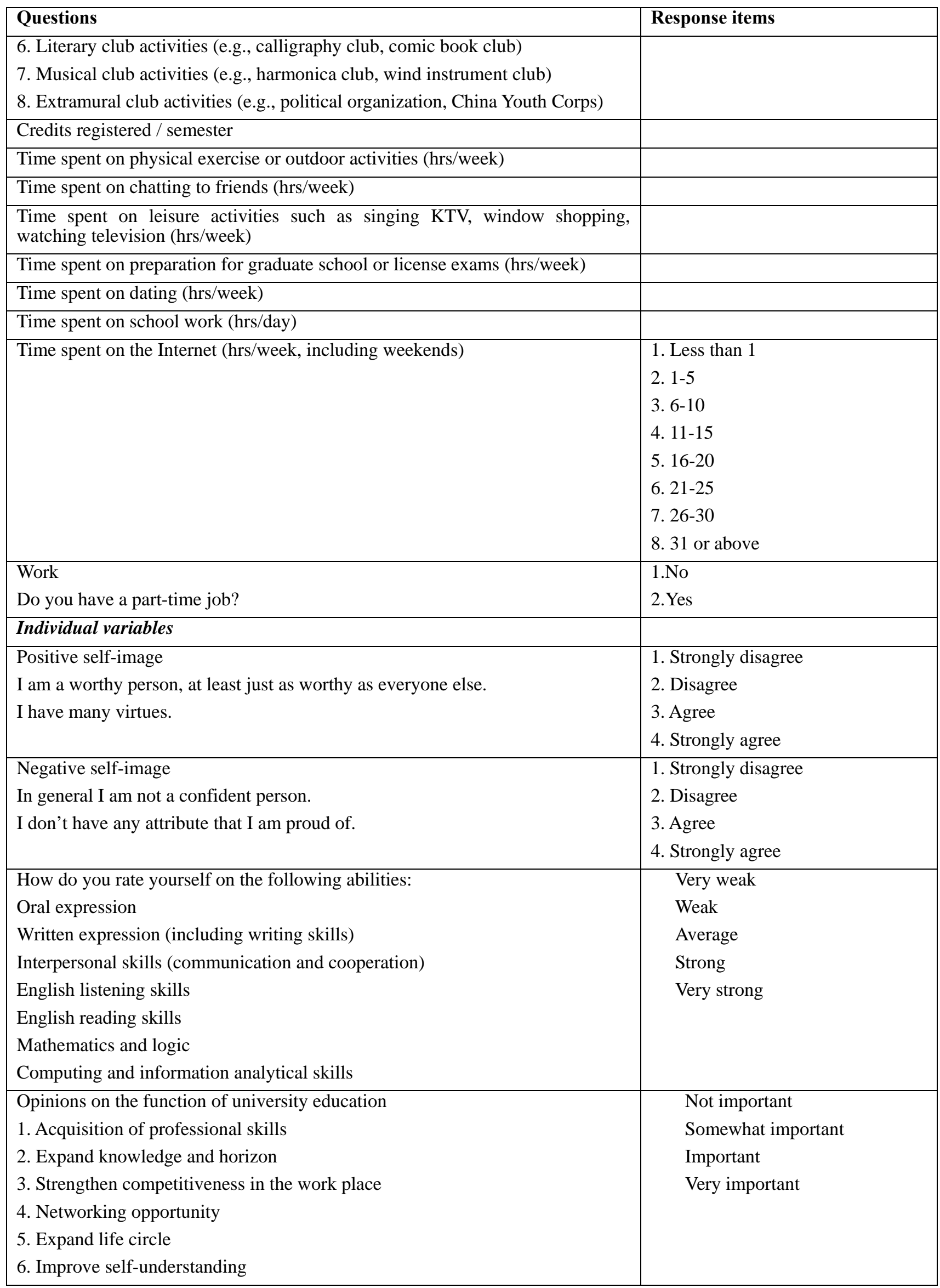




\begin{tabular}{|c|c|}
\hline Questions & Response items \\
\hline \multicolumn{2}{|l|}{ 7. Increase knowledge about the world, society, and environment. } \\
\hline $\begin{array}{l}\text { How important are the following life goals to you? } \\
\text { 1. Become an expert in an area } \\
\text { 2. Have an extraordinary contribution in certain area } \\
\text { 3. Become an entrepreneur } \\
\text { 4. To be influential in the society } \\
\text { 5. Have a happy family } \\
\text { 6. Live an abundant material life } \\
\text { 7. Lead a quality spiritual life } \\
\text { 8. Mastery of a foreign language } \\
\text { 9. Undertake meaningful work }\end{array}$ & $\begin{array}{l}\text { Not important } \\
\text { Somewhat important } \\
\text { Important } \\
\text { Very important }\end{array}$ \\
\hline \multicolumn{2}{|l|}{ Environmental variables } \\
\hline Living expenses assistance & $\begin{array}{l}\text { 1. Supported by parents or relatives } \\
\text { 2. Self-support (savings, income) } \\
\text { 3. Grant or scholarship } \\
\text { 4. Loan } \\
\text { 5. Others }\end{array}$ \\
\hline Tuition fee assistance & $\begin{array}{l}\text { 1. Supported by parents or relatives } \\
\text { 2. Self-support (savings, income) } \\
\text { 3. Grant or scholarship } \\
\text { 4. Loan } \\
\text { 5. Others }\end{array}$ \\
\hline Institution category & $\begin{array}{l}\text { Four-year vocational university } \\
\text { Four-year vocational college }\end{array}$ \\
\hline Institution type (public or private) & $\begin{array}{l}\text { Public institution or private } \\
\text { institution }\end{array}$ \\
\hline
\end{tabular}


Table 5. Descriptive statistics of variables

\begin{tabular}{|c|c|c|c|}
\hline Variable & $\%$ & Variable & $\%$ \\
\hline \multicolumn{2}{|l|}{ Type of institution } & \multicolumn{2}{|c|}{ Annual household income (NT\$: US\$ = 1: 0.033) } \\
\hline $\begin{array}{l}\text { Public university of science and } \\
\text { technology }\end{array}$ & 21.9 & Less than NT\$500 000 & 56.9 \\
\hline Public technical college & 8.8 & NT\$500 $000-1140000$ & 34.7 \\
\hline Public vocational college & 0.3 & NT\$1 $150000-1500000$ & 5.1 \\
\hline $\begin{array}{l}\text { Private university of science } \\
\text { and technology }\end{array}$ & 38.4 & NT\$1 $510000-3000000$ & 2.3 \\
\hline Private technical college & 26.6 & NT\$3 $010000-5000000$ & 0.6 \\
\hline Private vocational college & 4.0 & Above NT\$5 010000 & 0.3 \\
\hline Total & 100.0 & Total & 100.0 \\
\hline \multicolumn{2}{|l|}{ Mather’s Education Level } & \multicolumn{2}{|l|}{ Paternal educational level } \\
\hline Primary school or below & 38.3 & Primary school or below & 28.4 \\
\hline Junior high school & 30.8 & Junior high school & 23.2 \\
\hline $\begin{array}{l}\text { High school or vocational } \\
\text { school }\end{array}$ & 21.8 & High school or vocational school & 33.7 \\
\hline Community college & 5.8 & Community college & 10.2 \\
\hline University & 2.5 & University & 3.4 \\
\hline Graduate school or above & 0.8 & Graduate school or above & 1.0 \\
\hline Total & 100.0 & Total & 100.0 \\
\hline \multicolumn{2}{|l|}{ Gender } & \multicolumn{2}{|l|}{ GPA } \\
\hline Male & 46.0 & Below 59 percent & 9.0 \\
\hline Female & 54.0 & 60-69 percent & 33.3 \\
\hline Total & 100.0 & 70-79 percent & 44.5 \\
\hline & & 80-89 percent & 13.1 \\
\hline & & Total & 100.0 \\
\hline
\end{tabular}


Table 6. Chi-square analysis of parental and mothers' educational levels and household income by institutional type

\begin{tabular}{|c|c|c|c|c|c|}
\hline & $\begin{array}{l}\text { Public 4-year } \\
\text { vocational } \\
\text { university }\end{array}$ & $\begin{array}{l}\text { Public 4-year } \\
\text { vocational } \\
\text { college }\end{array}$ & $\begin{array}{l}\text { Private } 4 \text {-year } \\
\text { vocational } \\
\text { university }\end{array}$ & $\begin{array}{l}\text { Private } \\
\text { 4-year } \\
\text { vocational } \\
\text { college }\end{array}$ & $\chi^{2}$ \\
\hline Paternal educational level & & & & & $* * *$ \\
\hline Primary school or below & $25.3 \%$ & $27.5 \%$ & $32.0 \%$ & $26.2 \%$ & \\
\hline Junior high school & 28.6 & 20.0 & 17.1 & 27.9 & \\
\hline $\begin{array}{l}\text { High school or vocational } \\
\text { school }\end{array}$ & 29.4 & 32.5 & 36.2 & 34.5 & \\
\hline Community college & 10.2 & 10.0 & 10.7 & 9.6 & \\
\hline University & 3.3 & 10.0 & 3.4 & 1.7 & \\
\hline Graduate school or above & 3.3 & 0 & 0.6 & 0 & \\
\hline Mather's educational level & & & & & $* *$ \\
\hline Primary school or below & 31.6 & 42.5 & 37.4 & 45.9 & \\
\hline Junior high school & 32.0 & 31.3 & 32.0 & 27.9 & \\
\hline $\begin{array}{l}\text { High school or vocational } \\
\text { school }\end{array}$ & 27.9 & 8.8 & 22.2 & 18.8 & \\
\hline Community college & 5.3 & 7.5 & 5.3 & 6.1 & \\
\hline University & 2.0 & 6.3 & 2.5 & 1.3 & \\
\hline Graduate school or above & 1.2 & 3.8 & 0.6 & 0 & \\
\hline \multicolumn{6}{|l|}{ Annual household income } \\
\hline Less than NT\$500 000 & 57.6 & 56.6 & 56.6 & 56.8 & \\
\hline NT\$ $500000-1140000$ & 33.5 & 31.6 & 34.9 & 36.9 & \\
\hline NT\$1 $150000-1500000$ & 5.3 & 5.3 & 4.8 & 5.0 & \\
\hline NT\$1 $510000-3000000$ & 2.4 & 6.6 & 2.8 & 0.0 & \\
\hline NT\$3 $010000-5000000$ & 0 & 0 & 0.8 & 1.4 & \\
\hline Above NT\$5 010000 & 1.2 & 0 & 0 & 0 & \\
\hline
\end{tabular}

$* \mathrm{p}<.05 \quad * * \mathrm{P}<.01 \quad * * * \mathrm{p}<.001$ 
Table 7. Chi-square analysis of club participation, Internet usage, and working status

\begin{tabular}{|c|c|c|c|c|c|}
\hline & $\begin{array}{l}\text { Public } \\
\text { 4-year } \\
\text { vocational } \\
\text { university }\end{array}$ & $\begin{array}{l}\text { Public } \\
\text { 4-year } \\
\text { vocational } \\
\text { college }\end{array}$ & $\begin{array}{l}\text { Private } \\
\text { 4-year } \\
\text { vocational } \\
\text { university }\end{array}$ & $\begin{array}{l}\text { Private } \\
\text { 4-year } \\
\text { college }\end{array}$ & $\chi^{2}$ \\
\hline $\begin{array}{l}\text { Autonomous club activities } \\
\text { department student association) }\end{array}$ & & & & & $*$ \\
\hline Never & $43.8 \%$ & $56.0 \%$ & $44.4 \%$ & $47.2 \%$ & \\
\hline Seldom & 21.1 & 9.9 & 22.0 & 18.0 & \\
\hline Sometimes & 19.1 & 23.1 & 24.9 & 18.9 & \\
\hline Often & 15.9 & 11.0 & 8.7 & 15,5 & \\
\hline $\begin{array}{l}\text { Sports club activities (e.g., sport team, } \\
\text { kendo team) }\end{array}$ & & & & & $* * *$ \\
\hline Never & 43.4 & 42.4 & 45.7 & 56.7 & \\
\hline Seldom & 27.1 & 21.7 & 23.9 & 12.6 & \\
\hline Sometimes & 13.1 & 26.1 & 19.6 & 16.9 & \\
\hline Often & 16.3 & 9.8 & 10.9 & 13.9 & \\
\hline $\begin{array}{l}\text { Community service club activities (e.g., } \\
\text { scouts club, fraternity society) }\end{array}$ & & & & & $* *$ \\
\hline Never & 63.2 & 64.5 & 54.6 & 69.3 & \\
\hline Seldom & 23.5 & 24.7 & 26.9 & 16.0 & \\
\hline Sometimes & 6.5 & 4.3 & 14.4 & 10.0 & \\
\hline Often & 6.9 & 6.5 & 4.1 & 4.8 & \\
\hline $\begin{array}{l}\text { Artistic club activities (e.g., art club, } \\
\text { dance club) }\end{array}$ & & & & & $* *$ \\
\hline Never & 64.9 & 74.7 & 60.4 & 69.7 & \\
\hline Seldom & 23.1 & 7.7 & 23.0 & 15.2 & \\
\hline Sometimes & 8.4 & 8.8 & 13.3 & 12.6 & \\
\hline Often & 3.6 & 8.8 & 3.3 & 2.6 & \\
\hline $\begin{array}{l}\text { General club activities (e.g., alumni } \\
\text { association) }\end{array}$ & & & & & $*$ \\
\hline Never & 74.9 & 73.9 & 61.2 & 69.4 & \\
\hline Seldom & 16.7 & 19.6 & 26.3 & 20.7 & \\
\hline Sometimes & 6.0 & 6.5 & 11.1 & 9.9 & \\
\hline Often & 2.4 & 0 & 1.4 & 0 & \\
\hline $\begin{array}{l}\text { Literature club } \quad \text { activities } \\
\text { calligraphy club, comic book club) }\end{array}$ & & & & & $* * *$ \\
\hline Never & 77.2 & 78.3 & 63.6 & 75.0 & \\
\hline Seldom & 16.4 & 14.1 & 26.4 & 15.1 & \\
\hline Sometimes & 3.6 & 7.6 & 10.1 & 8.6 & \\
\hline Often & 2.8 & 0 & 0 & 1.3 & \\
\hline $\begin{array}{l}\text { Musical club activities (e.g., harmonica } \\
\text { club, wind instrument club) }\end{array}$ & & & & & $* * *$ \\
\hline
\end{tabular}




\begin{tabular}{|c|c|c|c|c|c|}
\hline & $\begin{array}{l}\text { Public } \\
\text { 4-year } \\
\text { vocational } \\
\text { university }\end{array}$ & $\begin{array}{l}\text { Public } \\
\text { 4-year } \\
\text { vocational } \\
\text { college }\end{array}$ & $\begin{array}{l}\text { Private } \\
\text { 4-year } \\
\text { vocational } \\
\text { university }\end{array}$ & $\begin{array}{l}\text { Private } \\
\text { 4-year } \\
\text { college }\end{array}$ & $\chi^{2}$ \\
\hline Never & 67.2 & 67.4 & 56.8 & 69.7 & \\
\hline Seldom & 20.4 & 13.0 & 23.4 & 17.7 & \\
\hline Sometimes & 4.8 & 19.6 & 15.2 & 9.1 & \\
\hline Often & 7.6 & 0 & 4.6 & 3.5 & \\
\hline \multicolumn{2}{|c|}{$\begin{array}{l}\text { Extramural club activities (e.g., political organization, } \\
\text { China Youth Corps) }\end{array}$} & & & & $* * *$ \\
\hline Never & 74.0 & 70.7 & 61.0 & 76.5 & \\
\hline Seldom & 19.2 & 12.0 & 25.5 & 12.6 & \\
\hline Sometimes & 4.8 & 14.1 & 11.1 & 6.1 & \\
\hline Often & 2.0 & 3.3 & 2.2 & 4.8 & \\
\hline \multicolumn{3}{|c|}{$\begin{array}{l}\text { Time spent on the Internet (average } \\
\text { hours per week including weekends) }\end{array}$} & & & $* * *$ \\
\hline Less than1 & 1.2 & 0 & 2.5 & 4.7 & \\
\hline $1-5$ & 17.6 & 12.7 & 22.8 & 39.6 & \\
\hline $6-10$ & 36.7 & 39.2 & 35.9 & 36.2 & \\
\hline $16-20$ & 15.1 & 3.8 & 10.9 & 6.0 & \\
\hline $21-25$ & 6.9 & 17.7 & 10.6 & 4.3 & \\
\hline $26-30$ & 4.9 & 7.6 & 6.7 & 2.6 & \\
\hline Above 31 & 17.6 & 19.0 & 10.6 & 6.5 & \\
\hline \multicolumn{6}{|c|}{$\begin{array}{l}\text { Are you working } \\
\text { semester? }\end{array}$} \\
\hline No & 55.8 & 69.7 & 55.1 & 56.3 & \\
\hline Yes & 44.2 & 30.3 & 44.9 & 43.7 & \\
\hline
\end{tabular}

${ }^{*} \mathrm{p}<.05 \quad * * \mathrm{P}<.01 \quad * * * \mathrm{p}<.001$ 
Table 8. Chi-square analysis of Aboriginal students' self-image, self-estimates of abilities, opinions on the function of university education and on their life goals

\begin{tabular}{|c|c|c|c|c|c|}
\hline & $\begin{array}{l}\text { Public } \\
\text { 4-year } \\
\text { vocational } \\
\text { university }\end{array}$ & $\begin{array}{l}\text { Public } \\
\text { 4-year } \\
\text { vocational } \\
\text { college }\end{array}$ & $\begin{array}{l}\text { Private } \\
\text { 4-year } \\
\text { vocational } \\
\text { university }\end{array}$ & $\begin{array}{l}\text { Private } \\
\text { 4-year } \\
\text { vocational } \\
\text { college }\end{array}$ & $\chi^{2}$ \\
\hline \multicolumn{3}{|l|}{ I am a worthy person. } & & & $*$ \\
\hline Disagree or Strongly Disagree & $22.8 \%$ & $21.3 \%$ & $24.7 \%$ & $19.2 \%$ & \\
\hline Agree or Strongly Agree & 77.2 & 78.8 & 75.2 & 80.9 & \\
\hline I have many virtues & & & & & $* * *$ \\
\hline Disagree or Strongly Disagree & 23.8 & 36.3 & 20.5 & 27.7 & \\
\hline Agree or Strongly Agree & 76.2 & 63.8 & 79.6 & 72.2 & \\
\hline \multicolumn{2}{|l|}{ In general I am not a confident person } & & & & $*$ \\
\hline Disagree or Strongly Disagree & 46.4 & 48.1 & 42.4 & 47.4 & \\
\hline Agree or Strongly Agree & 53.7 & 51.9 & 57.6 & 52.6 & \\
\hline \multicolumn{2}{|l|}{ I don't have any attribute that I am proud of } & & & & $* *$ \\
\hline Disagree or Strongly Disagree & 59.6 & 51.9 & 48.3 & 47.0 & \\
\hline Agree or Strongly Agree & 40.4 & 48.1 & 51.7 & 53.1 & \\
\hline \multicolumn{6}{|l|}{ Ability } \\
\hline Oral expression & & & & & $* * *$ \\
\hline Weak or Very Weak & 31.6 & 37.9 & 31.8 & 30.8 & \\
\hline Average & 50.0 & 50.6 & 52.1 & 49.6 & \\
\hline Strong or Very Strong & 18.5 & 11.4 & 16.1 & 19.6 & \\
\hline $\begin{array}{l}\text { Written expression (including writing } \\
\text { skills) }\end{array}$ & & & & & $* * *$ \\
\hline Weak or Very Weak & 42.8 & 35.4 & 33.0 & 43.9 & \\
\hline Average & 42.4 & 49.4 & 56.1 & 43.0 & \\
\hline Strong or Very Strong & 14.7 & 15.2 & 11.0 & 13.0 & \\
\hline $\begin{array}{l}\text { Interpersonal skills (communication } \\
\text { and cooperation) }\end{array}$ & & & & & $*$ \\
\hline Weak or Very Weak & 12.7 & 3.8 & 15.7 & 11.8 & \\
\hline Average & 49.4 & 64.6 & 52.5 & 45.4 & \\
\hline Strong or Very Strong & 38.0 & 31.7 & 31.8 & 42.8 & \\
\hline English listening skills & & & & & $* * *$ \\
\hline Weak or Very Weak & 54.1 & 58.2 & 67.3 & 64.8 & \\
\hline Average & 36.9 & 26.6 & 31.3 & 27.8 & \\
\hline Strong or Very Strong & 9.0 & 15.2 & 1.4 & 7.4 & \\
\hline English reading skills & & & & & $* * *$ \\
\hline Weak or Very Weak & 52.0 & 57.0 & 62.9 & 61.3 & \\
\hline Average & 40.2 & 36.7 & 34.3 & 33.9 & \\
\hline Strong or Very Strong & 7.8 & 6.3 & 2.8 & 4.8 & \\
\hline Mathematics and logic & & & & & $* * *$ \\
\hline
\end{tabular}




\begin{tabular}{|c|c|c|c|c|c|}
\hline & $\begin{array}{l}\text { Public } \\
\text { 4-year } \\
\text { vocational } \\
\text { university }\end{array}$ & $\begin{array}{l}\text { Public } \\
\text { 4-year } \\
\text { vocational } \\
\text { college }\end{array}$ & $\begin{array}{l}\text { Private } \\
\text { 4-year } \\
\text { vocational } \\
\text { university }\end{array}$ & $\begin{array}{l}\text { Private } \\
\text { 4-year } \\
\text { vocational } \\
\text { college }\end{array}$ & $\chi^{2}$ \\
\hline Weak or Very Weak & 53.9 & 47.5 & 61.0 & 67.5 & \\
\hline Average & 38.8 & 37.5 & 33.6 & 27.3 & \\
\hline Strong or Very Strong & 7.4 & $15.0 \%$ & $5.3 \%$ & $5.2 \%$ & \\
\hline \multicolumn{6}{|l|}{$\begin{array}{l}\text { Computing and information analytical } \\
\text { skills }\end{array}$} \\
\hline Weak or Very Weak & 40.2 & 48.1 & 38.3 & 42.2 & \\
\hline Average & 48.8 & 36.7 & 51.5 & 42.6 & \\
\hline Strong or Very Strong & 11.1 & 15.2 & 10.1 & 15.2 & \\
\hline \multicolumn{6}{|c|}{$\begin{array}{l}\text { Please rate the importance of the following functions of university } \\
\text { Education }\end{array}$} \\
\hline \multicolumn{6}{|l|}{ Acquisition of professional skills } \\
\hline Not Important & 2.4 & 0 & 0.8 & 1.3 & \\
\hline Somewhat Important & 11.0 & 10.0 & 16.6 & 12.6 & \\
\hline Important & 42.9 & 36.3 & 42.8 & 36.1 & \\
\hline Very Important & 43.7 & 53.8 & 39.7 & 50.0 & \\
\hline Expand knowledge and horizon & & & & & $* * *$ \\
\hline Not Important & 1.2 & 0 & 1.4 & 0 & \\
\hline Somewhat Important & 7.8 & 7.5 & 16.6 & 11.7 & \\
\hline Important & 40.6 & 23.8 & 41.6 & 40.4 & \\
\hline Very Important & 50.4 & 68.8 & 40.4 & 47.8 & \\
\hline $\begin{array}{l}\text { Strengthen competitiveness in the } \\
\text { work place }\end{array}$ & & & & & $* *$ \\
\hline Not Important & 0 & 2.5 & 4.0 & 1.3 & \\
\hline Somewhat Important & 15.9 & 16.5 & 16.7 & 13.0 & \\
\hline Important & 38.8 & 21.5 & 41.5 & 37.4 & \\
\hline Very Important & 45.3 & 59.5 & 37.9 & 48.3 & \\
\hline Networking opportunity & & & & & $*$ \\
\hline Not Important & 0 & 0 & 0.8 & 0.9 & \\
\hline Somewhat Important & 8.2 & 2.5 & 13.5 & 15.3 & \\
\hline Important & 39.8 & 45.6 & 43.4 & 38.0 & \\
\hline Very Important & 52 & 51.9 & 42.3 & 45.9 & \\
\hline \multicolumn{6}{|l|}{ Expand life circle } \\
\hline Not Important & 0 & 0 & 0.6 & 0 & \\
\hline Somewhat Important & 9.4 & 11.4 & 12.6 & 11.5 & \\
\hline Important & 40.2 & 36.7 & 43.8 & 41.0 & \\
\hline Very Important & 50.4 & 51.9 & 43.0 & 47.6 & \\
\hline Improve self-understanding & & & & & \\
\hline
\end{tabular}




\begin{tabular}{|c|c|c|c|c|c|}
\hline & $\begin{array}{l}\text { Public } \\
\text { 4-year } \\
\text { vocational } \\
\text { university }\end{array}$ & $\begin{array}{l}\text { Public } \\
\text { 4-year } \\
\text { vocational } \\
\text { college }\end{array}$ & $\begin{array}{l}\text { Private } \\
\text { 4-year } \\
\text { vocational } \\
\text { university }\end{array}$ & $\begin{array}{l}\text { Private } \\
4 \text {-year } \\
\text { vocational } \\
\text { college }\end{array}$ & $\chi^{2}$ \\
\hline Not Important & 1.2 & 0 & 0.6 & 0 & \\
\hline Somewhat Important & 8.2 & 8.9 & 12.4 & 9.7 & \\
\hline Important & 34.8 & 39.2 & 39.5 & 36.1 & \\
\hline Very Important & 55.7 & 51.9 & 47.5 & 54.2 & \\
\hline $\begin{array}{l}\text { Increase knowledge about the world, } \\
\text { society, and environment }\end{array}$ & & & & & $*$ \\
\hline Not Important & 1.2 & 0 & 0.6 & 0.6 & \\
\hline Somewhat Important & 13.9 & 12.7 & 14.4 & 14.8 & \\
\hline Important & 37.6 & 31.6 & 46.9 & 35.2 & \\
\hline Very Important & 47.3 & 55.7 & 38.1 & 47.6 & \\
\hline \multicolumn{6}{|l|}{$\begin{array}{l}\text { How important are the following life } \\
\text { goals to you? }\end{array}$} \\
\hline \multicolumn{6}{|l|}{ Become an expert in an area } \\
\hline Not Important & 4.9 & 7.5 & 8.8 & 9.1 & \\
\hline Somewhat Important & 20.5 & 15.0 & 28.5 & 22.2 & \\
\hline Important & 45.1 & 48.8 & 39.5 & 38.7 & \\
\hline Very Important & 29.5 & 28.8 & 23.2 & 30.0 & \\
\hline $\begin{array}{l}\text { Have an extraordinary contribution in } \\
\text { certain area }\end{array}$ & & & & & $* *$ \\
\hline Not Important & 4.5 & 8.8 & 8.5 & 3.1 & \\
\hline Somewhat Important & 24.1 & 11.3 & 27.3 & 20.1 & \\
\hline Important & 43.7 & 45.0 & 39.7 & 46.7 & \\
\hline Very Important & 27.8 & 35.0 & 24.5 & 30.1 & \\
\hline Become an entrepreneur & & & & & $* * *$ \\
\hline Not Important & 2.0 & 11.3 & 4.5 & 1.7 & \\
\hline Somewhat Important & 14.7 & 10.0 & 19.7 & 14.0 & \\
\hline Important & 42.0 & 25.0 & 44.2 & 43.2 & \\
\hline Very Important & 41.2 & 53.8 & 31.5 & 41.0 & \\
\hline \multicolumn{6}{|l|}{ To be influential in the society } \\
\hline Not Important & 13.1 & 13.8 & 14.1 & 15.2 & \\
\hline Somewhat Important & 33.2 & 28.8 & 29.3 & 22.6 & \\
\hline Important & 31.1 & 22.5 & 36.1 & 34.8 & \\
\hline Very Important & 22.5 & 35.0 & 20.6 & 27.4 & \\
\hline Have a happy family & & & & & $* *$ \\
\hline Not Important & 3.3 & 2.5 & 4.8 & 0 & \\
\hline Somewhat Important & 8.6 & 6.3 & 12.4 & 5.3 & \\
\hline Important & 27.8 & 26.6 & 29.9 & 34.8 & \\
\hline Very Important & 60.4 & 64.6 & 53.0 & 59.9 & \\
\hline
\end{tabular}




\begin{tabular}{|c|l|l|l|l|l|}
\hline & $\begin{array}{l}\text { Public } \\
\text { 4-year } \\
\text { vocational } \\
\text { university }\end{array}$ & $\begin{array}{l}\text { Public } \\
\text { 4-year } \\
\text { vocational } \\
\text { college }\end{array}$ & $\begin{array}{l}\text { Private } \\
\text { 4-year } \\
\text { vocational } \\
\text { university }\end{array}$ & $\begin{array}{l}\text { Private } \\
\text { 4-year } \\
\text { vocational } \\
\text { college }\end{array}$ & $\chi^{2}$ \\
\hline Live an abundant material life & & & & & $* *$ \\
\hline Not Important & 4.9 & 11.4 & 7.9 & 2.2 & \\
\hline Somewhat Important & 22.9 & 13.9 & 26.8 & 25.1 & \\
\hline Important & 42.0 & 58.2 & 42.8 & 48.5 & \\
\hline Very Important & 30.2 & 16.5 & 22.5 & 24.2 & \\
\hline Lead a quality spiritual life & & & & & \\
\hline Not Important & 0 & 2.5 & 3.4 & 2.6 & \\
\hline Somewhat Important & 13.5 & 8.8 & 15.8 & 12.6 & \\
\hline Important & 40.6 & 42.5 & 41.7 & 42.2 & \\
\hline Very Important & 45.9 & 46.3 & 39.2 & 42.6 & \\
\hline Mastery of a foreign language & & & & & \\
\hline Not Important & 0 & 0 & 5.1 & 0.9 & \\
\hline Somewhat Important & 14.3 & 15.0 & 22.5 & 14.0 & \\
\hline Important & 40.4 & 46.3 & 39.2 & 43.7 & \\
\hline Very Important & 45.3 & 38.8 & 33.2 & 41.5 & \\
\hline Undertake meaningful work & & & & & \\
\hline Not Important & 1.2 & 0 & 2.0 & 0.9 & \\
\hline Somewhat Important & 12.7 & 6.3 & 15.2 & 9.1 & \\
\hline Important & 36.3 & 33.8 & 40.0 & 35.2 & \\
\hline Very Important & 49.8 & 60.0 & 42.8 & 54.8 & \\
\hline
\end{tabular}

$*=\mathrm{p}<.05 \quad * *=\mathrm{P}<.01 \quad * * *=\mathrm{p}<.001$ 
Table 9. Comparisons of group means on time spent on weekly activities and average course mark for aboriginal students

\begin{tabular}{|c|c|c|c|c|c|}
\hline Question & $\begin{array}{l}\text { Public } \\
\text { 4-year } \\
\text { public } \\
\text { university }\end{array}$ & $\begin{array}{l}\text { Public } \\
\text { 4-year } \\
\text { vocational } \\
\text { college }\end{array}$ & $\begin{array}{l}\text { Private } \\
\text { 4-year } \\
\text { private } \\
\text { university }\end{array}$ & $\begin{array}{l}\text { Private } \\
\text { 4-year } \\
\text { vocational } \\
\text { college }\end{array}$ & $\mathbf{P}$ \\
\hline Number of credits / semester & 23.5 & 23.5 & 21.8 & 20.3 & $* *$ \\
\hline $\begin{array}{l}\text { Time spent on physical exercise or outdoor } \\
\text { activities ( hrs / week) }\end{array}$ & 5.5 & 6.3 & 4.2 & 4.7 & $*$ \\
\hline $\begin{array}{l}\text { Time spent on chatting to friends ( hrs / } \\
\text { week) }\end{array}$ & 8.2 & 8.7 & 8.5 & 7.3 & \\
\hline $\begin{array}{l}\text { Time spent on leisure activities such as } \\
\text { shopping, watching television (hrs / } \\
\text { week) }\end{array}$ & 6.3 & 8.6 & 9.1 & 7.8 & $*$ \\
\hline $\begin{array}{l}\text { Time spent on preparation for cramp school } \\
\text { or license exams ( hrs/ week) }\end{array}$ & 2.9 & 1.8 & 2.5 & 2.5 & \\
\hline Time spent on dating (hrs/ week) & 4.4 & 3.3 & 4.7 & 4.2 & \\
\hline $\begin{array}{l}\text { Time spent per day on class preparation, } \\
\text { assignments, and revision }\end{array}$ & 3.1 & 2.9 & 2.8 & 2.3 & $* *$ \\
\hline GPA $(100 \%)$ & 68.2 & 71 & 68.3 & 69.0 & \\
\hline
\end{tabular}

Table 10. Regression analysis of the educational aspirations of aboriginal students enrolled in vocational institutions

\begin{tabular}{|l|c|l|}
\hline Variable & Standardised & \multicolumn{2}{l}{ Regression } \\
\hline Tuition fee assistance & -.052 & \\
\hline Living expenses assistance & -.044 & \\
\hline Life goals at the societal level & .075 & \\
\hline Life goals at the individual level & .011 & \\
\hline Interpersonal skills & .271 & $* * *$ \\
\hline English language skills & .005 & \\
\hline Mathematical and computing skills & .052 & \\
\hline Positive self-image & -.016 & \\
\hline Negative self-image & -.015 & \\
\hline Number of Credits / semester & .115 & $* *$ \\
\hline Time spent on leisure activities & -.025 & \\
\hline Time spent on class preparation and revision & .078 & $*$ \\
\hline Autonomous club activities & .155 & $* * *$ \\
\hline Sports club activities & -.104 & $*$ \\
\hline Community service club activities & -.072 & \\
\hline Artistic club activities & -.004 & \\
\hline General club activities & .032 & \\
\hline Literature club activities & .230 & $* * *$ \\
\hline
\end{tabular}




\begin{tabular}{|l|c|l|}
\hline Variable & Standardised & \multicolumn{2}{|c|}{ Regression } \\
\hline Coefficient $\beta$ & -.106 & $*$ \\
\hline Musical club activities & .119 & $*$ \\
\hline Extramural club activities & -.19 & \\
\hline Opinions on the function of university education & .094 & $*$ \\
\hline GPA & .050 & \\
\hline Household income & -.027 & \\
\hline Paternal educational level & .112 & $* *$ \\
\hline Mother's educational level & .009 & \\
\hline Working status & -.075 & \\
\hline Weekly hours spent on the Internet & -.118 & $* *$ \\
\hline Being a female & .097 & $*$ \\
\hline Institutional type & .035 & \\
\hline Institution sector (public/private) & 0.293 & $* * *$ \\
\hline $\mathrm{R}^{2}$ & & \\
\hline
\end{tabular}

Level of significance of $F$ test: ${ }^{*}=\mathrm{p}<.05 \quad{ }^{* *}=\mathrm{p}<.01 \quad{ }^{* * *}=\mathrm{p}<.001$

\begin{tabular}{|l|}
\hline Background variables \\
\hline Gender \\
Paternal educational level \\
Mother's educational level \\
Annual household income \\
\hline
\end{tabular}

\section{Behavioural variables}

\section{GPA}

Participation in social clubs Credits / semester

Time spent on the Internet (hr/week)

Time spent on job (hr/week)

Leisure and social activities

Time sDent on studving

\section{Individual variables}

Positive self-image Negative self-image Interpersonal and communication skills

English ability

Math and computing ability

Life goal (societal)

Life goal (personal)

Opinions on the functions of

university education

\section{Environmental} variables

Living expenses subsidy

Tuition fee subsidy

Institutional type

Institutional sector

Figure 1. Research framework

\section{Educational} aspirations 